\title{
Assessing the persistence of some pasture legumes in hill country
}

S.J. ORR and M.E. WEDDERBURN AgResearch, Whatawhata Research Centre, Private Bag 3089, Hamilton, New Zealand

\section{Abstract}

White clover (Trifolium repens) is the traditional pasture legume in New Zealand but its persistence and production in the low fertility, summer-dry hill country of the North Island is poor. In a preliminary trial to assess the persistence of alternative perennial legumes, two species, Adesmia bicolor and a prostrate cultivar of Trifolium pratense were studied over a 2-year period on an ash soil over a range of slopes, aspects and fertility levels. The $T$.pratense cultivar was still present at trial completion, contributing to higher total legume levels (9.5\%) than in the resident pasture plots $(7 \%)$. The second trial examined the potential of the previous two species along with accessions of Trifolium semipilosum, Trifolium fragiferum and T. repens (cv. Grasslands Prestige) over 3 years in a paddock of clay hill soil commencing in 1994. After 2 years the $T$.pratense and introduced $T$. repens lines were still present in the easy plots while the $T$. semipilosum cultivar was the only introduced legume to persist on the steeper slopes. The mean total legume content on both steep and easy slopes from the last harvest (April 1996)_was_similar-to pre-trial levels. The persisting introduced legumes "replaced" resident species rather than increasing total legume levels. The potential of the prostrate T. pratense cultivar for use in hill country should be further investigated.

K eywords: Adesmia, hill country, legumes, low fertility, persistence, Trifolium repens

\section{Introduction}

In the low fertility, summer-dry hill country pastures of the North Island of New Zealand legume populations tend to be sparse and unevenly distributed (Suckling et al. 1983; MacFarlane \& Sheath 1984). The content of white clover (Trifolium repens) declines as fertility declines and moisture stress decreases. This reduction in legumecontent results in less nitrogen being available for the associated pasture grasses, with a resultant decline in pasture production. A persistent and productive legume base in these harsher conditions would be advantageous.
A research programme was initiated to assess the persistence and contribution to pasture production of alternative legumes in low fertility, summer-dry hill country.

From 1990 to 1993 a series of trials to assess the potential of a number of accessions of non-traditional pasture legume species for growth in low fertility summer dry conditions was undertaken at AgResearch Whatawhata Research Centre (Dodd \& Orr 1995). From these glasshouse-based trials the most promising species were chosen for further evaluation under field conditions.

\section{Background}

In a preliminary trial to assess the persistence of alternative perennial legumes, two species, Adesmia bicolor and a prostrate Trifolium pratense, along with T. repens (cv. Grasslands Tahora), were studied over a Z-year period on an ash soil over a range of slopes, aspects and fertility levels.

After the initial establishment period (April 1993 to April 1994) T.pratense was found in higher levels on easy slopes and in the south-facing plots. A slight -response-to-phosphateadition was noted throughout the trial. At trial completion (April 1995) levels of total legume $(7 \%)$ were similar in the resident, $A$. bicolor and $T$. repens plots while levels in the $T$. pratense plots, were higher at approximately $9.5 \%$. The most encouraging factor was continued persistence of $T$. pratense even after intermittent sheep grazing pressure was introduced onto the trial site (Orr 1995).

A. bicolor failed to persist in the location chosen for this trial. However, the performance of this legume on the steep north-facing slopes suggested that if may have had potential for even harsher, less densely populated locations.

Some findings could be drawn from the first trial, but initial results were somewhat inconclusive. For this reason a second field trial was initiated in 1994.

\section{M ethods}

The legumes studied in this trial are listed in Table 1.

The trial incorporated 48 plots $(0.55 \mathrm{~m} \times 0.7 \mathrm{~m})$, laid out on a low fertility site on Kaawa Hill Soil (yellowbrown earth/fulvic: Bruce 1978). Pre-trial soil fertility 
levels were: $\mathrm{pH}$ 4.8-5.0, phosphate retention 49-61\%, Olsen $P$ range 8-12.

Trial design was a factorial arrangement of 2 slope classes $\times 6$ species (5 introduced species and resident pasture) x 4 replicates. Slope classes were easy (10$\left.22^{\circ}\right)$ and steep (25-35”).

Eighteen seedlings (approximately 6 weeks old) were transplanted into the plots in a diagonal grid $450 \times 400$ $\mathrm{mm}$ with $125 \mathrm{~mm}$ spacing between plants. The new legumes were transplanted into the steep plots on 19 May 1994 and introduced into the easy plots on 21 June 1994. This time differential allowed the plants in the harsher environment of the steep plots extra time to establish themselves before the winter. To avoid plant pulling by the grazing animals, plots were caged and cut with handpieces $(20-30 \mathrm{~mm})$ during the first year of the trial. After this establishment period the plots were opened up to the rotational grazing treatment imposed on the paddock (40-day rotation, set-stocked with sheep in spring).

\section{Measurements}

Since trial inception (May-June 1994) the following measurements have been taken:

1. Monthly cover scores from a single quadrat $\mathbf{0} 0.125$ $\mathrm{m}^{2}$ ) were undertaken to determine the ground cover characteristics of the plots and more specifically the spreading behaviour of the introduced legumes. This method measures the species present at 40 randomly selected points within the plots. The data gathered were used in conjunction with dissection measurements to assess pasture composition changes over time. These monthly surveys began in July 1994 and the categories assessed were grasses, weed, white clover, other legumes (Trifolium subterranean, Lotus spp.), new legumes and bare ground.

2. Species dissections were undertaken on herbage from single quadrats $\left(0.125 \mathrm{~m}^{2}\right)$ to determine the contribution of the introduced species to the pasture composition. These harvests were carried out on:

- 17 May 1994 (pre-planting)

- 2 November 1994

- 6 March 1995

. 30 August 1995

- 1 April 1996

Plot areas were caged to exclude animals one month prior to the harvest date.

The dissection categories were similar to those used for the cover scores.
Table 1 Plant material used.

\begin{tabular}{lll}
\hline Species & Cultivar & Inoculum \\
\hline Adesmia bicolor & AL 2842 & NZP 5252 \\
Trifolium pratense & Astred & PDD 2668 \\
Trifolium repens & Grasslands Prestige & PDD 2668 \\
Trifolium fragiferum & Grasslands Onward & PDD 2668 \\
Trifolium semipilosum & Safari & ICMP 2173 \\
\hline
\end{tabular}

The 1995 late summer harvest (6 March 1995) was undertaken after a prolonged dry summer. On-site rainfall December 1994 to February 1995 was $186 \mathrm{~mm}$ and the mean 30-year figure (1951-1980) for this period of the year is $323 \mathrm{~mm}$ (New Zealand Meteorological Service 1987).

In the plots where the T. repens cultivar Grasslands Prestige was introduced the new legume percentage was calculated by subtracting the $T$. repens in the resident plots from the total $T$. repens percentage in the Prestige plots.

The cover score data were analysed using a Generalised Linear Model with logarithmic link and binomial error distribution with Genstat, and the dissection data were analysed using ANOVA in the Genstat package.

\section{Results and discussion}

\section{Pasture cover scores}

$T$. pratense was the most prevalent of the introduced legumes on the easy slopes (Figure I), with spring 1995 levels in excess of $30 \%$, and it continued to persist under the grazing regime which has been in place since September 1995. Astred has the unique feature of being able to reproduce both by seed and vegetatively through stolons and daughter plants. These characteristics help this accession to survive and withstand close grazing (Smith \& Bishop 1993).

The introduced $T$. repens also persisted well on the easy slopes (Figure 1), with spring 1995 cover score levels above $15 \%$. Prestige in North Island hill country has shown markedly improved clover growth on dry northern aspects and in early spring (Cooper \& Chapman 1993). Those plots where Prestige was introduced tended to have a higher total $T$.repens content $(8.1 \%)$ than the resident pasture plots $(6.3 \%)$ on the easy slopes at the date of the last measurements (March 1996). Both the introduced $T$.pratense and $T$. repens cultivars struggled to survive on the steep slopes, levels falling to below 3\% by January 1996 (Figure 2).

$T$. semipilosum failed to persist in the easy plots but at March 1996 was the only introduced species present on the steeper slopes (Figure 2), identifying this species as a stress tolerator at these sites. $T$. repens and $T$. 


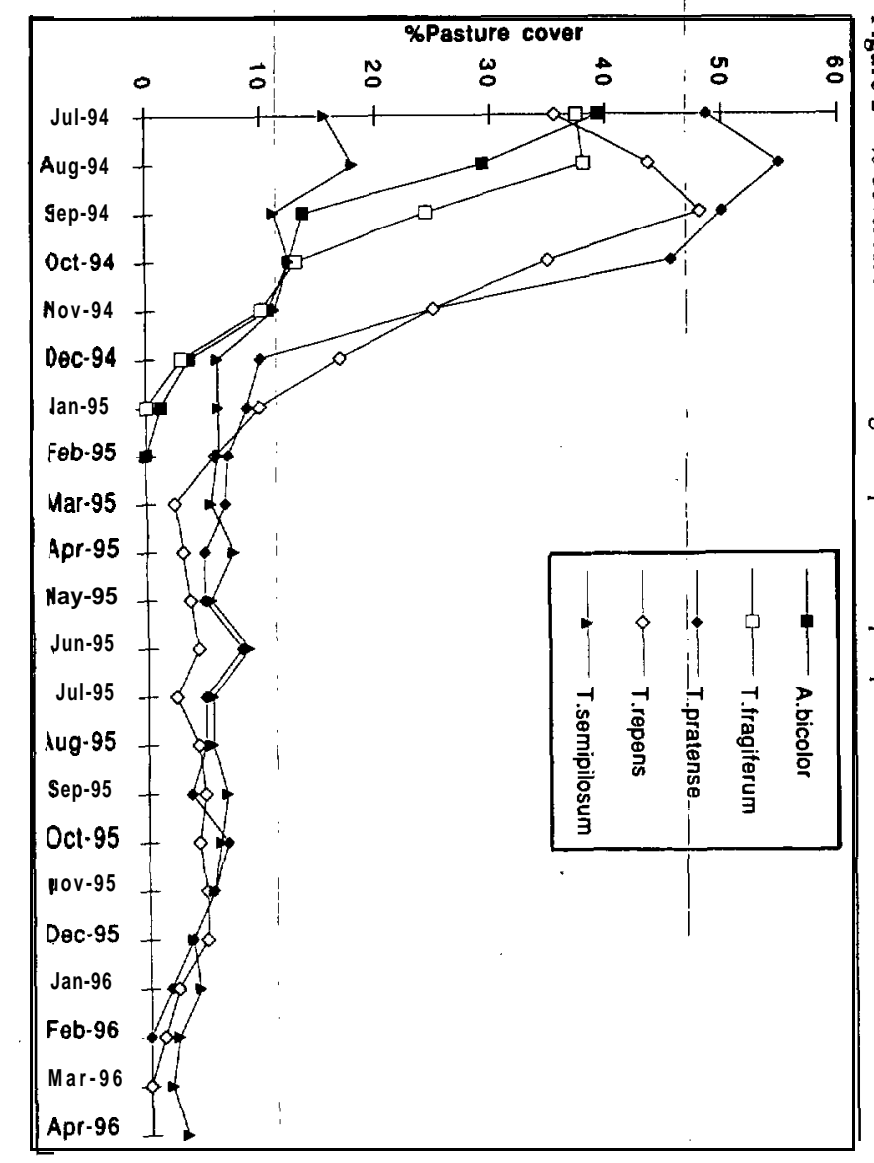


Figure 3 Pasture composition on easy slopes.

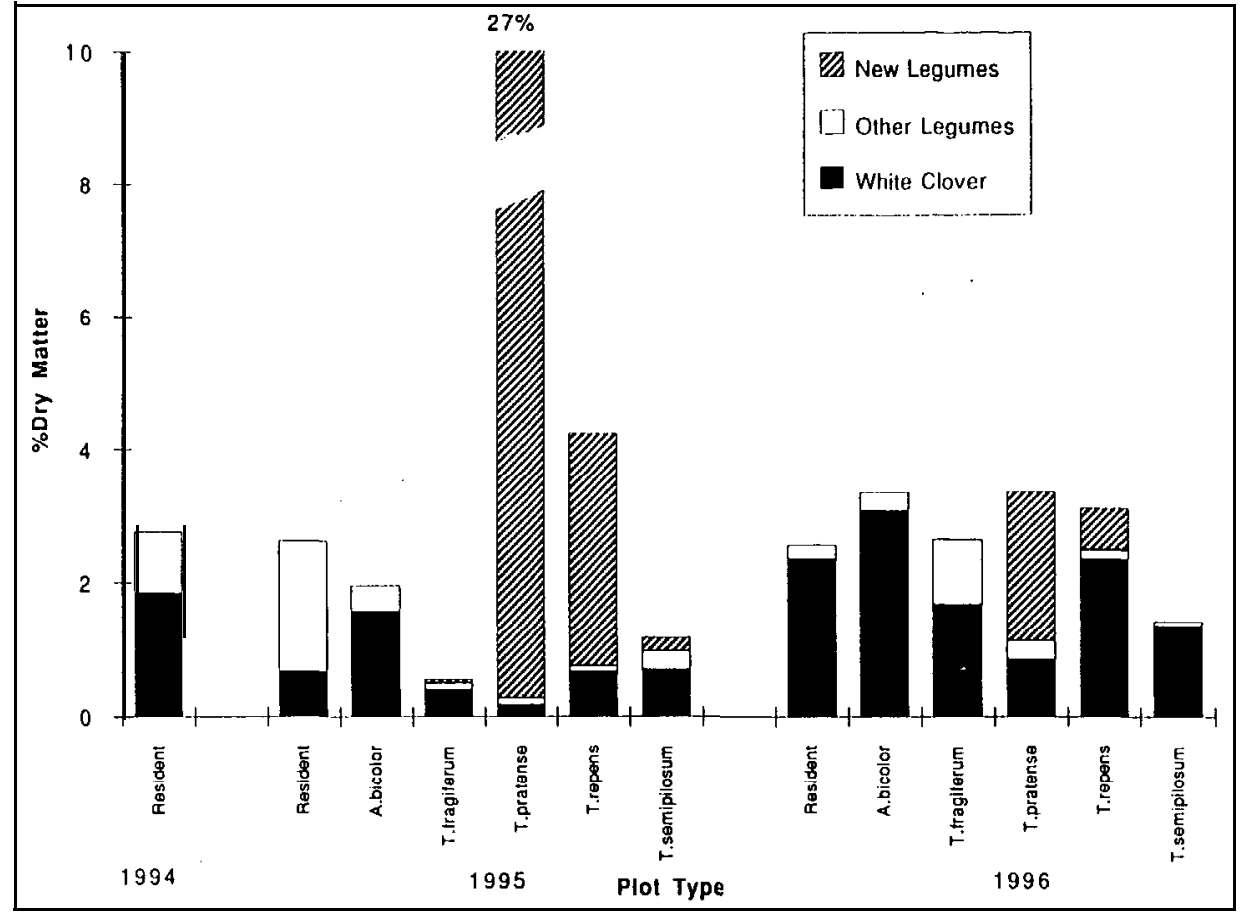

Figure 4 Pasture composition on steep slopes.

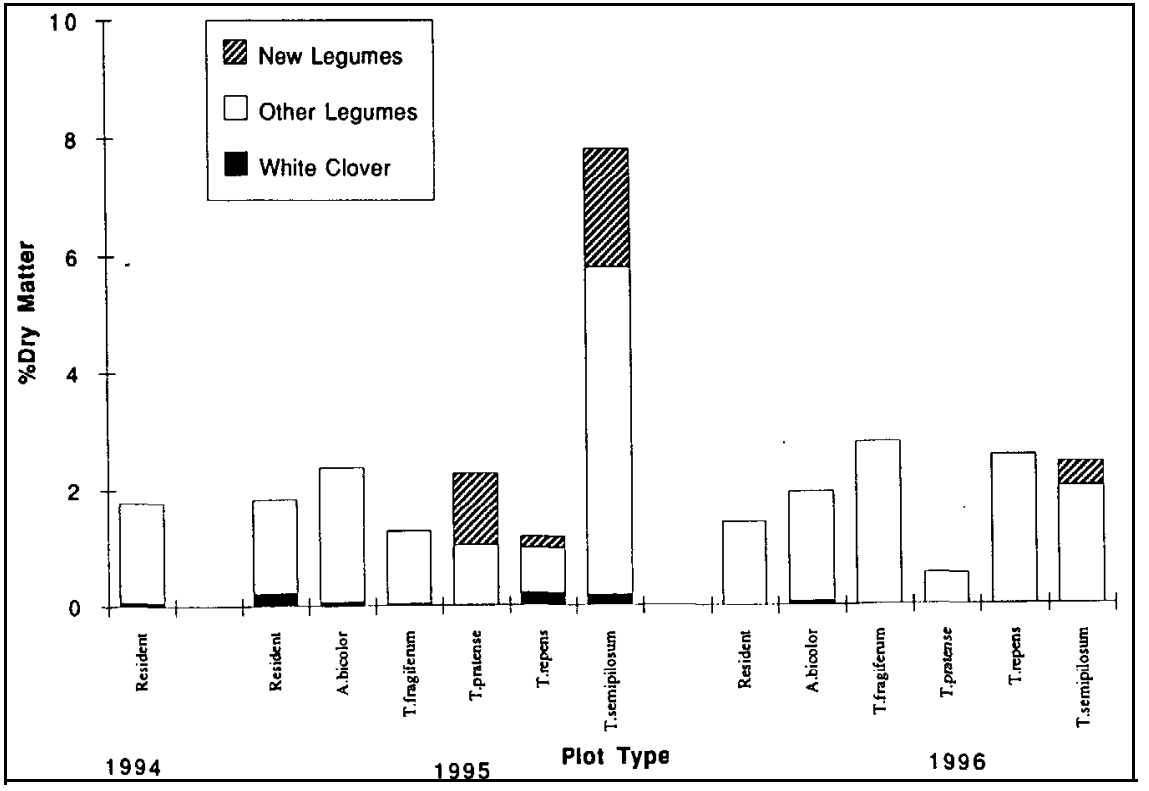

Previous work (Dodd \& Orr 1995) had shown the A. bicolor, $T$. fragiferum and T. semipilosum lines to be slower growing than $T$. pratense and $T$. repens. $A$. bicolor and T. fragiferum had disappeared from both the steep and easy plots by mid 1995 (Figures 1, 2). These slower-growing species may have failed to persist 
on the easy slopes because of the presence of the more vigorous grass species, which were better able to compete for resources (light, moisture, nutrients).

$T$. fragiferum is vegetatively similar to $T$. repens but is more commonly used in moist, poorly drained or even saline soils (Rumball et al. 1991), which is vastly different to the environment found on the steep slopes of the trial.

Root nodules taken from the introduced $A$. bicolor plants 6 months after planting showed the presence of only the native rhizobia ( $\mathrm{H}$. Pryor, pers. comm.). Earlier studies (Dodd \& Orr 1995) had shown A. bicolor to have relatively low levels of both protein and nitrogen content. Protein is often calculated from nitrogen percentage in plant material, and this suggests the poor nodulation success could have limited the species performance.

\section{Pasture composition}

The pre-trial dissections (May 1994) showed the average total legume content of the plots was below $3 \%$ and grass species dominated $(70-75 \%)$. Total legume content rose significantly ( $P \$ 0.001$ ) to $20 \%$ by the date of the first post legume introduction harvest (November 1994). Mean total legume figures before the introduction of grazing (August 1995) were down to $7 \%$ and declined further to levels similar to those of the pre-trial measurements by the latest harvest in April 1996. There was a significant (P \$0.005) seasonal effect, with levels of total legume higher in the spring $(7.1 \%)$ than in the late summer harvests $(4.6 \%-1995$, $2.4 \%-1996)$.

In the 1995 late summer harvest $T$. prufense and $T$. repens contributed significantly $(\mathrm{P} \leq 0.001)$ more to pasture composition than the other introduced legumes in the easy plots (Figure 3). By the April 1996 harvest, levels of these legumes had declined (T. prutense $2.5 \%, T$. repens $-0.7 \%)$ under grazing. This decrease coincided with a morphological change in the $T$. pratense cultivar, with a predominance of the prostrate growth habit in 1996 as opposed to the more erect growth of April 199.5. The very high contribution of $T$. -pratense (27\%) in 1995 (Figure -3) occurred-during-the establishment phase of the trial when the plots were defoliated mechanically to simulate a lax grazing treatment. This is consistent with studies recently undertaken at AgResearch Grasslands (Hyslop et al. 1996). The mean total legume content on the easy slopes from the last harvest (April 1996) showed levels similar to those of the pretrial measurements (Figure 3 ).

There was a significantly higher level $(P \leq 0.001)$ of resident $T$. repens in the easy plots compared with the steep throughout the trial (Figure 3). Resident $T$. repens levels, which had fallen away in the 1995 late summer harvest following a prolonged dry summer, recovered to levels similar to those pre-trial by the April 1996 harvest (Figure 3).

The percentage present of the other resident legume species (T. subterranean, Lotus spp.) was higher in the steep plots (Figure 4) than the easy throughout the trial period. Given these species formed the bulk of the total legume (Figure 4), future investigations should be directed towards improving cultivars of these species rather than seeking new species.

Data from the April 1996 harvest showed that, of the introduced legumes, only the $T$. semipilosum accession $(0.4 \%)$ was contributing to pasture composition on the steep slopes (Figure 4). In the 1995 late summer harvest there was a significant increase (PI 0.001 ) of the other resident legumes (T. subterranean, Lotus spp.) in the $T$. semipilosum plots compared with the other introduced species plots on the steep slopes (Figure 4). This effect had occurred within the establishment period of the trial when the plots were being maintained with handpieces to simulate a lax grazing treatment. As in the easy plots mean total legume levels in the steep plots from the April 1996 harvest $(2.0 \%)$ were similar to those of the pre-planting harvest (1.8\%).

On both the steep and easy slopes the persistent introduced legume species "replaced" resident legumes. This did not increase total legume levels. The potential of the prostrate $T$. pratense cultivar for use in the hill country should be further investigated.

\section{- Conclusions........ . .}

The introduced $T$. repens and $T$.pratense were the only two species to persist in the easy plots. Both of these species proved tolerant of the cutting and grazing regime imposed. T. semipilosum was the only introduced legume to persist in the steep plots. This species was more suited to harsher environment (i.e., lower fertility, summer dry, open pasture and higher soil temperature) of the steep slopes.

Two of the introduced legume species, A. bicolor and $-T$. fragiferum, failed ${ }^{-}$to $^{-}$survive ${ }^{-}$beyond the -first summer of the trial (March 1995) on both the easy and the steep slopes.

After the first two years of the trial, total legume levels on both the steep and easy slopes were similar to pre-trial figures, suggesting the persistent legume species (T. pratense, $T$. repens and $T$. semipilosum) had replaced resident species, rather than increasing the total legume levels.

The potential of the prostrate $T$. pratense cultivar for use in hill country should be further investigated. 


\section{ACKNOWLEDGEMENTS}

The authors wish to thank Gavin Sheath, Mike Dodd, Bill Pengelly, lan Tarbotton and Alec McGowan for helpful discussion. Linda Trolove for technical assistance and Martin Upsdell of the Ruakura Computing Group for statistical analysis.

\section{REFERENCES}

Bruce, J.G. 1978. Soils of part Raglan County, South Auckland New Zealand Bureau bulletin 41. Wellington, New Zealand: Soil Bureau DSIR.

Cooper, B.M.: Chapman, D.F. 1993. Grasslands Prestige (G39), a white clover originating from northern New Zealand. Proceedings of the XVII Grassland Congress: 458-459.

Date. R.A.: Roughley, R.J. 1986. Effects of root temperature on the growth and nitrogen fixation of Trifolium semipilosum and Trifolium repens. Experimental agriculture 22: 133-147.

Dodd, M.B.: Orr. S.J. 1995. Seasonal growth, phosphate response and drought tolerance of eleven perennial legume species grown in a hill country soil. New Zealand journal of agricultural research 38: 7-20.

Hyslop, M.G.: Kemp, R.D.; Barker, D.J.; Hodgson, J. 1996. The incidence of nodal rooting and plantlet survival in spreading red clovers (Trifolium pratense
L.). Proceedings of the New Zealand Grassland Association 58: (this volume).

MacFarlane, M.J.; Sheath, G.W. 1984. Clover - What types for hill country? Proceedings of the New Zealand Grassland Association 45:140-150.

New Zealand Meteorological Service 1987: Summary of Climatological Observations to 1980. NZ Met. Service miscellaneous publication 177: 39-40.

Orr, S.J. 1995. Suitability of Adesmia bicolor and Trifolium pratense for growth and persistence in North Island hill country. Internal report, AgResearch, Whatawhata Research Centre.

Rumball, W.; Claydon, R.B.; Miller, J.E. 1991. 'Grasslands Onward' strawberry clover. New Zealand journal of agricultural research 34: 131133.

Sheath, G.W.; Boom, R.C. 1985. Effects of NovemberApril grazing pressure on hill country pastures. 3. Interrelationship with soil and pasture variation. New Zealand journal of experimental agriculture, 13: $341-349$.

Smith, R.S.; Bishop, D.J. 1993. Astred - a stoloniferous Red clover. Proceedings of the XVII International Grassland Congress: 421-423.

Suckling, F.E.T.; Forde, M.B.; Williams, W.M. 1983. Naturalised subterranean clover in New Zealand. New Zealand journal of agricultural research 26: 35-43. 